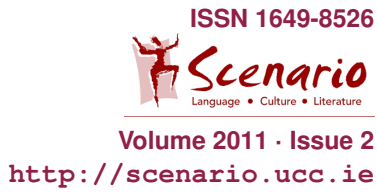

Texts around Theatre

\title{
Prelude at the Theatre
}

\section{from: FAUST by Johann Wolfgang von Goethe}

In this rubric we present various perspectives on theatre - historical and contemporary, intercultural and culture-specific, unexpectedly weird, unusually suspenseful, disturbedly gripping, fascinatingly enigmatic ...

The following extract is taken from Johann Wolfgang von Goethe's tragedy FAUST (first published in 1808). A conversation between a theatre director, a writer (and a "merry person") revolves around a fundamental question: to what extent should the audience's desire for entertainment be the deciding factor when staging plays? Goethe worked on Faust nearly two centuries ago, but the text is still of high topicality nowadays, particularly in the face of increasing pressure on educational and cultural institutions. Indeed, the justification of performances is often intricately tied to measurable success (i.e. audience size). Apart from this we are looking at a downright pedagogical question: what plays should be staged, by which means, and to what end?

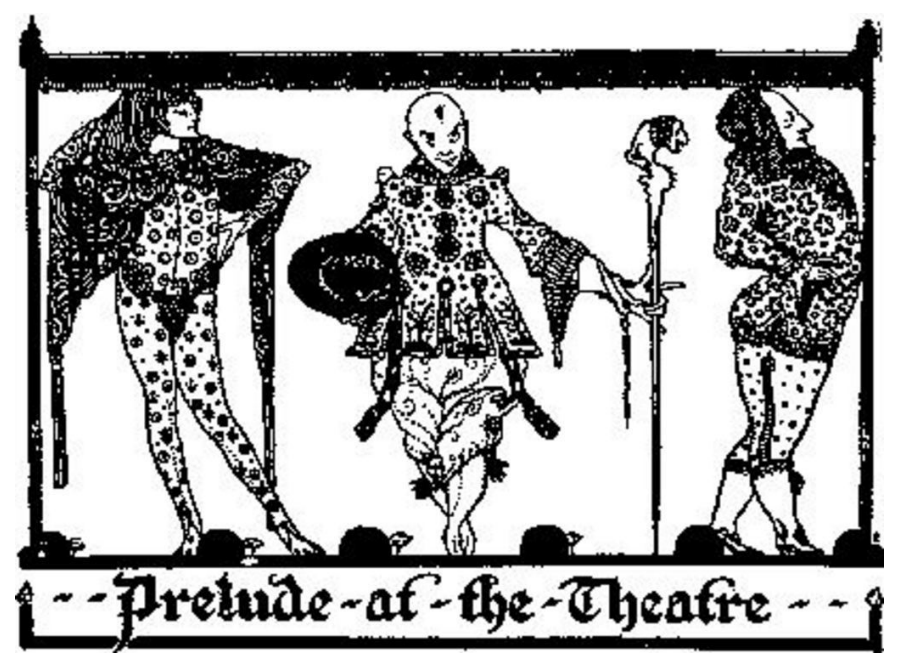

MANAGER — DRAMATIC POET — MERRY-ANDREW

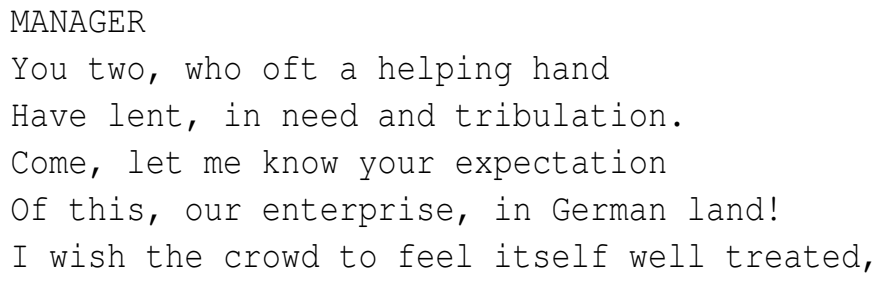
Attribution-NonCommercial-NoDerivatives 4.0 International License. 
Especially since it lives and lets me live;

The posts are set, the booth of boards completed.

And each awaits the banquet I shall give.

Already there, with curious eyebrows raised,

They sit sedate, and hope to be amazed.

I know how one the People's taste may flatter,

Yet here a huge embarrassment I feel:

What they're accustomed to, is no great matter,

But then, alas! they've read an awful deal.

How shall we plan, that all be fresh and new,-

Important matter, yet attractive too?

For 'tis my pleasure-to behold them surging,

When to our booth the current sets apace,

And with tremendous, oft-repeated urging,

Squeeze onward through the narrow gate of grace:

By daylight even, they push and cram in

To reach the seller's box, a fighting host,

And as for bread, around a baker's door, in famine,

To get a ticket break their necks almost.

This miracle alone can work the Poet

on men so various: now, my friend, pray show it.

POET

Speak not to me of yonder motley masses,

Whom but to see, puts out the fire of Song!

Hide from my view the surging crowd that passes,

And in its whirlpool forces us along!

No, lead me where some heavenly silence glasses

The purer joys that round the Poet throng,-

Where Love and Friendship still divinely fashion

The bonds that bless, the wreaths that crown his passion!

Ah, every utterance from the depths of feeling

The timid lips have stammeringly expressed,-

Now failing, now, perchance, success revealing,-

Gulps the wild Moment in its greedy breast;

Or oft, reluctant years its warrant sealing,

Its perfect stature stands at last confessed!

What dazzles, for the Moment spends its spirit:

What's genuine, shall Posterity inherit.

MERRY-ANDREW

Posterity! Don't name the word to me!

If _should choose to preach Posterity,

Where would you get contemporary fun?

That men _have it, there's no blinking:

A fine young fellow's presence, to my thinking,

Is something worth, to every one. 
Who genially his nature can outpour, Takes from the People's moods no irritation; The wider circle he acquires, the more Securely works his inspiration.

Then pluck up heart, and give us sterling coin!

Let Fancy be with her attendants fitted,Sense, Reason, Sentiment, and Passion join,But have a care, lest Folly be omitted! MANAGER

Chiefly, enough of incident prepare!

They come to look, and they prefer to stare. Reel off a host of threads before their faces, So that they gape in stupid wonder: then By sheer diffuseness you have won their graces, And are, at once, most popular of men. only by mass you touch the mass; for any Will finally, himself, his bit select: Who offers much, brings something unto many, And each goes home content with the effect, If you've a piece, why, just in pieces give it: A hash, a stew, will bring success, believe it! 'Tis easily displayed, and easy to invent. What use, a Whole compactly to present?

Your hearers pick and pluck, as soon as they receive it! POET

You do not feel, how such a trade debases; How ill it suits the Artist, proud and true! The botching work each fine pretender traces Is, I perceive, a principle with you. MANAGER

Such a reproach not in the least offends; A man who some result intends Must use the tools that best are fitting. Reflect, soft wood is given to you for splitting, And then, observe for whom you write! If one comes bored, exhausted quite, Another, satiate, leaves the banquet's tapers, And, worst of all, full many a wight Is fresh from reading of the daily papers. Idly to us they come, as to a masquerade, Mere curiosity their spirits warming:

The ladies with themselves, and with their finery, aid, Without a salary their parts performing.

What dreams are yours in high poetic places? You're pleased, forsooth, full houses to behold? 
Draw near, and view your patrons' faces!

The half are coarse, the half are cold.

One, when the play is out, goes home to cards;

A wild night on a wench's breast another chooses:

Why should you rack, poor, foolish bards,

For ends like these, the gracious Muses?

I tell you, give but more-more, ever more, they ask:

Thus shall you hit the mark of gain and glory.

Seek to confound your auditory!

To satisfy them is a task.-

What ails you now? Is't suffering, or pleasure?

POET

Go, find yourself a more obedient slave!

What! shall the Poet that which Nature gave,

The highest right, supreme Humanity,

Forfeit so wantonly, to swell your treasure?

Whence o'er the heart his empire free?

The elements of Life how conquers he?

Is't not his heart's accord, urged outward far and dim,

To wind the world in unison with him?

When on the spindle, spun to endless distance,

By Nature's listless hand the thread is twirled,

And the discordant tones of all existence

In sullen jangle are together hurled,

Who, then, the changeless orders of creation

Divides, and kindles into rhythmic dance?

Who brings the one to join the general ordination,

Where it may throb in grandest consonance?

Who bids the storm to passion stir the bosom?

In brooding souls the sunset burn above?

Who scatters every fairest April blossom

Along the shining path of Love?

Who braids the noteless leaves to crowns, requiting

Desert with fame, in Action's every field?

Who makes Olympus sure, the Gods uniting?

The might of Man, as in the Bard revealed.

MERRY-ANDREW

So, these fine forces, in conjunction,

Propel the high poetic function,

As in a love-adventure they might play!

You meet by accident; you feel, you stay,

And by degrees your heart is tangled;

Bliss grows apace, and then its course is jangled;

You're ravished quite, then comes a touch of woe,

And there's a neat romance, completed ere you know! 
Let us, then, such a drama give!

Grasp the exhaustless life that all men live!

Each shares therein, though few may comprehend:

Where'er you touch, there's interest without end.

In motley pictures little light,

Much error, and of truth a glimmering mite,

Thus the best beverage is supplied,

Whence all the world is cheered and edified.

Then, at your play, behold the fairest flower

of youth collect, to hear the revelation!

Each tender soul, with sentimental power,

Sucks melancholy food from your creation;

And now in this, now that, the leaven works.

For each beholds what in his bosom lurks.

They still are moved at once to weeping or to laughter,

Still wonder at your flights, enjoy the show they see:

A mind, once formed, is never suited after;

one yet in growth will ever grateful be.

POET

Then give me back that time of pleasures,

While yet in joyous growth I sang,-

When, like a fount, the crowding measures

Uninterrupted gushed and sprang!

Then bright mist veiled the world before me,

In opening buds a marvel woke,

As I the thousand blossoms broke,

Which every valley richly bore me!

I nothing had, and yet enough for youth-

Joy in Illusion, ardent thirst for Truth.

Give, unrestrained, the old emotion,

The bliss that touched the verge of pain,

The strength of Hate, Love's deep devotion,-

0 , give me back my youth again!

MERRY ANDREW

Youth, good my friend, you certainly require

When foes in combat sorely press you;

When lovely maids, in fond desire,

Hang on your bosom and caress you;

When from the hard-won goal the wreath

Beckons afar, the race awaiting;

When, after dancing out your breath,

You pass the night in dissipating:-

But that familiar harp with soul

To play,-with grace and bold expression,

And towards a self-erected goal 
To walk with many a sweet digression,-

This, aged Sirs, belongs to you,

And we no less revere you for that reason:

Age childish makes, they say, but 'tis not true;

We're only genuine children still, in Age's season!

MANAGER

The words you've bandied are sufficient;

'Tis deeds that I prefer to see:

In compliments you're both proficient,

But might, the while, more useful be.

What need to talk of Inspiration?

'Tis no companion of Delay.

If Poetry be your vocation,

Let Poetry your will obey!

Full well you know what here is wanting;

The crowd for strongest drink is panting,

And such, forthwith, I'd have you brew.

What's left undone to-day, To-morrow will not do.

Waste not a day in vain digression:

With resolute, courageous trust

Seize every possible impression,

And make it firmly your possession;

You'll then work on, because you must.

Upon our German stage, you know it,

Each tries his hand at what he will;

So, take of traps and scenes your fill,

And all you find, be sure to show it!

Use both the great and lesser heavenly light,-

Squander the stars in any number,

Beasts, birds, trees, rocks, and all such lumber,

Fire, water, darkness, Day and Night!

Thus, in our booth's contracted sphere,

The circle of Creation will appear,

And move, as we deliberately impel,

From Heaven, across the World, to Hell!

From: FAUST by Johann Wolfgang von Goethe. With illustrations

by Harry Clarke. Translated into English, in the origninal metres,

by Bayard Taylor. An illustrated edition. The World Publishing Company, Cleveland, Ohio, New York, N.Y.

http://www.gutenberg.org/files/14591/14591-h/14591-h.htm - 23-03-2012 